\title{
High Frequency Wide Output Range Boost-Flyback Converter with Zero Voltage
} Switching

Liu, Yuan; Dou, Yi; Du, Mingxing ; Wei, Kexin; Gerard, Hurley; Andersen, Michael A. E.; Ouyang, Ziwei

Published in:

Proceedings of 2nd IEEE International Power Electronics and Application Conference and Exposition

Link to article, DOI:

10.1109/PEAC.2018.8590669

Publication date:

2018

Document Version

Peer reviewed version

Link back to DTU Orbit

Citation $(A P A)$ :

Liu, Y., Dou, Y., Du, M., Wei, K., Gerard, H., Andersen, M. A. E., \& Ouyang, Z. (2018). High Frequency Wide Output Range Boost-Flyback Converter with Zero Voltage Switching. In Proceedings of 2nd IEEE International Power Electronics and Application Conference and Exposition IEEE. https://doi.org/10.1109/PEAC.2018.8590669

\section{General rights}

Copyright and moral rights for the publications made accessible in the public portal are retained by the authors and/or other copyright owners and it is a condition of accessing publications that users recognise and abide by the legal requirements associated with these rights.

- Users may download and print one copy of any publication from the public portal for the purpose of private study or research.

- You may not further distribute the material or use it for any profit-making activity or commercial gain

- You may freely distribute the URL identifying the publication in the public portal 


\title{
High Frequency Wide Output Range Boost-Flyback Converter with Zero Voltage Switching
}

\author{
Yuan Liu ${ }^{1}$, Yi Dou ${ }^{2}$, Mingxing $\mathrm{Du}^{1}$, Kexin $\mathrm{Wei}^{1}$, Hurley Gerard ${ }^{1}$, Michael A.E.Andersen ${ }^{2}$ and Ziwei Ouyang ${ }^{2}$ \\ ${ }^{1}$ School of Electrical and Engineering,Tianjin University of Technology,Tian jin, China \\ ${ }^{2}$ Electrical Engineering,Technical University of Denmark, Copenhagen, Denmark \\ zo@elektro.dtu.dk
}

\begin{abstract}
DC-DC converters with high step-up capability are increasingly used in sustainable energy, aerospace and high voltage direct current (HVDC) systems. This paper presents a high voltage step-up dc-dc converter with low voltage stress on the switches and with a wide output range. High-frequency operation with zero voltage switching (ZVS) may be accomplished, in order to shrink the size and to increase the efficiency of the converter. ZVS turn-on is possible in all the switches by the same principle as an active clamp structure. The detailed ZVS condition and design considerations are discussed in the paper. A $100 \mathrm{~W} 28 \mathrm{~V}$ to maximum $400 \mathrm{~V}$ prototype is designed and its peak efficiency of $95 \%$ has been achieved.

Keywords-boost-flyback converter, ZVS turn-on, high gain converter, high frequency converter, wide output range
\end{abstract}

\section{INTRODUCTION}

Nowadays, rapid developments are taking place for sustainable energy including fuel cells and photovoltaics, in order to protect the environment and save energy. Thus, the need for high efficiency, high power density, high voltage step-up dc-dc converters are needed to feed power to the grid[1], [2], [3], [4]. Besides, high voltage step-up dc-dc converters are also widely used in aerospace industries and for high voltage direct current (HVDC) power transmission systems [5], [6]. The conventional boost converter can be used while the duty cycle needs to be extremely high to ach sufficiently high voltage gain, where it would result in large power loss and less controlability [2], [7]. Several topologies utilize high turns ratio in coupling inductors; transformers or switch-cap hybrid structures to achieve high boost capability [8], [9], [10].

The boost-flyback converter is one of the best solutions for

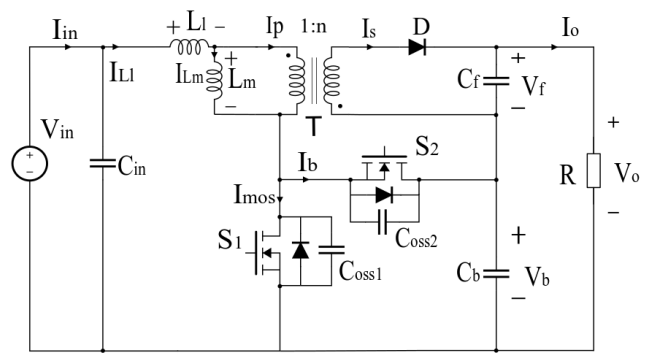

Fig. 1: Boost-flyback converter topology

high step-up applications with the benefits of low voltage stress on the switches; high step-up capability and voltage adjustment capability [11], [12]. In order to further shrink the size of the converter, higher switching frequencies can be considered to decrease the size of the passive components especially the inductors. In this paper a Zero Voltgae Switching (ZVS) boost-flyback converter with high-frequency operation for solar battery applications is proposed. The operation of the ZVS turn-on transient is introduced and we will show that ZVS turn-on can be realized both with Continuous Conduction Mode(CCM) and Discontinuous Conduction Mode (DCM). The experimental prototype will show that the ZVS can be realized and the peak efficiency can reach $95 \%$ with $100 \mathrm{~W}$ output.

\section{PRINCIPLE OPERATION}

The active-clamp structure is widely used in flyback converters to achieve ZVS turn-on and to reduce switching losses on the low-side switches. In boost-flyback converters an intrinsic active-clamp consisting of a switch and a capacitor can be used to achieve soft-switching for both high-side and low-side switches.

The topology of the proposed ZVS boost-flyback converter is illustrated in Fig. 1 and the key waveforms in DCM are illustrated in Fig. 3. Fig. 2 shows eight operational subintervals which may be described as follows:

Mode 1[Fig. 2(a), $t_{0}<t<t_{1}$ ] At $t_{0}$, main switch $S_{1}$ is turned on, and boost switch $S_{2}$ and $D$ are off. The magnetizing inductance $L_{m}$ and the leakage inductance $L_{l}$ are charged by the input voltage. During this period, the output capacitors $C_{f}$ and $C_{b}$ are discharged to support the output voltage.

Mode 2[Fig. 2(b), $t_{1}<t<t_{2}$ ]At $t_{1}$, the main switch $S_{1}$ is turned off, the parasitic output capacitor of switch $S_{1}$ is charged from $0 \mathrm{~V}$ to $V_{i n}+\frac{V_{f}}{n} \approx V_{b}+V_{\text {Coss } 2}$. Where $V_{i n}$ is input voltage, $V_{f}$ is output voltage of flyback part, $V_{b}$ is the output voltage of boost part, $V_{\text {Coss } 2}$ is voltage of parasitic output capacitor with siwtch $S_{2}$. The resonant circuit is composed of $C_{o s s 1}$. $L_{l}$ and $L_{m}$. The magnetixing current is given as equation (1) and the current can be estimated by equation (2)

$$
\begin{gathered}
i_{L m}=i_{L m}\left(t_{1}\right) \cos \left(\omega_{1}\left(t-t_{1}\right)\right)+\frac{V_{i n}}{Z_{1}} \sin \left(\omega_{1}\left(t-t_{1}\right)\right) \\
i_{L m}(t)=i_{L m}\left(t_{1}\right)+\frac{V_{i n}-V_{1}}{L_{m}}\left(t-t_{1}\right)
\end{gathered}
$$




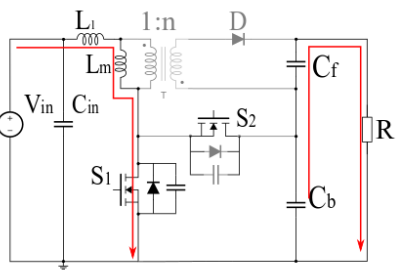

(a)

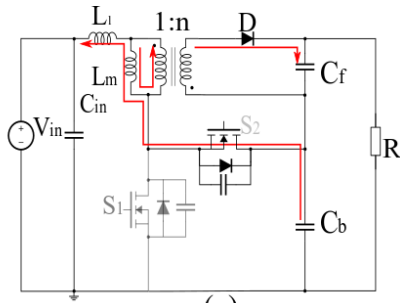

(e)

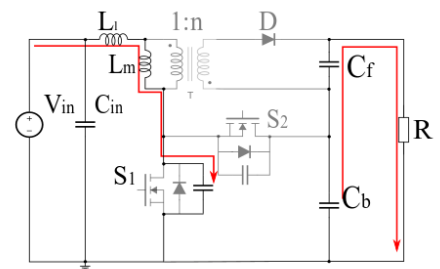

(b)

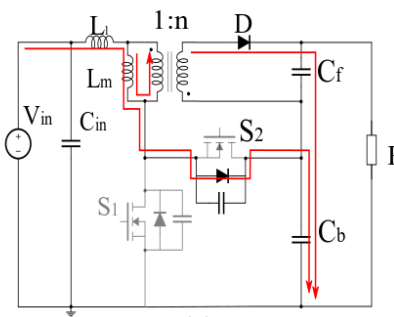

(c)

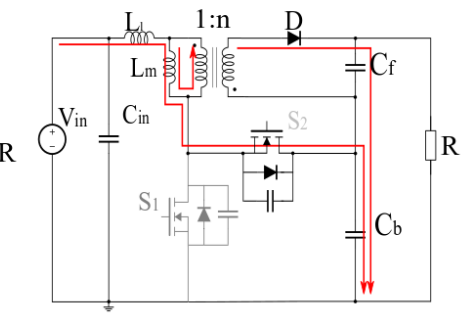

(d)

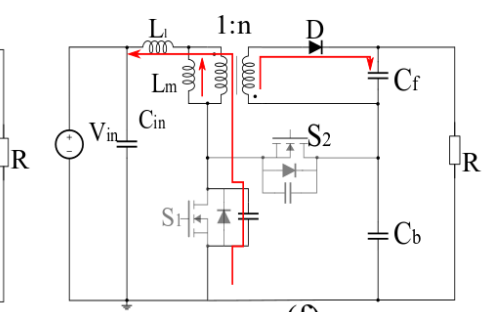

(f)

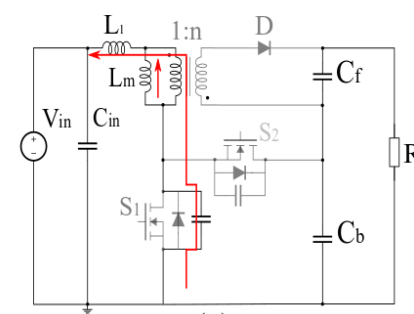

(g)

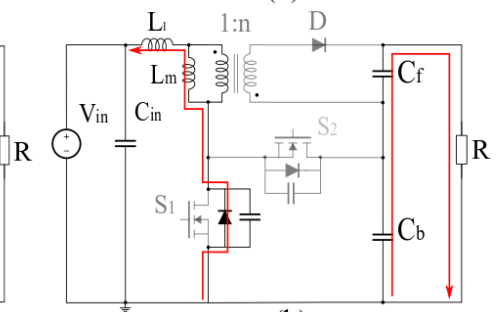

(h)

Fig. 2: Operating Modes of Proposed Converter

$$
\omega_{1}=\frac{1}{\sqrt{C_{o s s 1}\left(L_{m}+L_{l}\right)}}, Z_{1}=\sqrt{\frac{L_{m}+L_{l}}{C_{o s s 1}}}
$$

In this period, the voltage of the parasitic output capacitance $V_{C o s s 1}$ is less than $V_{i n}+n V_{f}$ so that no current flows through the boost switch $S_{2}$, therefore $i_{b}(t)=0$.

Mode3[Fig. 2(c), $t_{2}<t<t_{3}$ ]At $t_{2}$, the body diode of the switch $S_{2}$ is turned on and the secondary diode $D$ is turned on. The leakage inductance $L_{l}$ and the boost capacitance $C_{b}$ begin to resonate. The energy stored in the magnetizing inductance is transferred to the output load. The magnetizing currents is decreased by the slope of $-n V_{f} / L_{m}$. In order to ensure ZVS and prevent the conduction loss resulting from the body diode of main switch $S_{2}$, this period is very short and is completed by the turn on the boost switch $S_{2}$.

Mode 4[Fig. 2(d), $t_{3}<t<t_{4}$ ] The system operation is similar to Mode 3 expect that the boost current flows through the boost switch $S_{2}$ instead of through its body diode. This period is ended when the boost current returns to zero.

Mode 5[Fig.2(e), $t_{4}<t<t_{5}$ ] The operation is again similar to Mode 4 except that the boost current is reversed. The period is ends when switch $S_{2}$ turns off.

Mode 6[Fig. 2(f), $t_{5}<t<t_{6}$ ] At $t_{5}$, switch $S_{2}$, turns off. The output capacitor of switch $S_{1}$ is discharged by the current through the leakage inductance. In this period, the secondary diode $D$ remains on and $V_{p r i}=-V_{f} / n$. This mode ends with diode $D$ being turned off.

Mode 7[Fig. 2(g), $t_{6}<t<t_{7}$ ] At $t_{6}$, the secondary diode $D$ is turned off. The leakage inductance current is equal to the magnetizing inductance current. This mode finishes when the voltage of parasitic output capacitor $C_{o s s 1}$ reaches $0 \mathrm{~V}$.

Mode 8[Fig. 2(h), $t_{7}<t<t_{0}$ ]At $t_{7}$, the body diode of switch $S_{1}$ is turned on. This mode is ended when the switch $S_{1}$ is turned on.

\section{MAGNETIC DESIGN CONSIDERATION}

In the ZVS boost-flyback converter, the transformer loss is the main limitation for achieving high efficiency. Determining the relevant parameters of the transformer is an important step. On the one hand, the magnetizing inductance is designed to be small enough to draw a reverse current, on the other hand, the large ripple current induces high conduction loss in the switch $S_{1}$ and in the windings.

\section{A. Voltage gain}

According to the capacitor $C_{f}$ and capacitor $C_{b}$ are enough large, the voltage of capacitor $C_{f}$ and capacitor $C_{b}$ are constant. The leakage inductance, winding resistance and transient characteristics of the MOSFET and DIODE are neglected.

Thus, equation is given as follows:

$$
\begin{aligned}
V_{C_{b}} & =\frac{V_{i n}}{1-D} \\
V_{C_{f}} & =\frac{n D V_{i n}}{1-D}
\end{aligned}
$$

where $\mathrm{n}$ is the turns ratio of the couple inductor. According the above equations, the ideal voltage gain of the boostflyback converter is given as equation (6).

$$
\frac{V_{o}}{V_{i n}}=\frac{1+n D}{1-D}
$$

\section{B. Magnetizing inductance}

The magnetizing inductance is designed for an output voltage of $200 \mathrm{~V}$ in DCM over full range. According to the equation:

$$
I_{\text {average }}=\frac{I_{m}}{D}
$$

where $I_{\text {average }}$ is the average value of the magnetizing current, $I_{m}$ is the input current. $D$ is the duty cycle of main switch $S_{1}$. According to the equation (6) and equation (7), $D_{200 \mathrm{~V}}<D_{400 \mathrm{~V}}$, we design the inductance with the equation:

$$
L_{m}=\frac{V_{i n} \times D T}{\Delta i}
$$

where $L_{m}$ is the magnetizing inductance. $\Delta i$ is the magnetizing current ripple equal to $I_{\text {average-200V }} T$ is the period. 


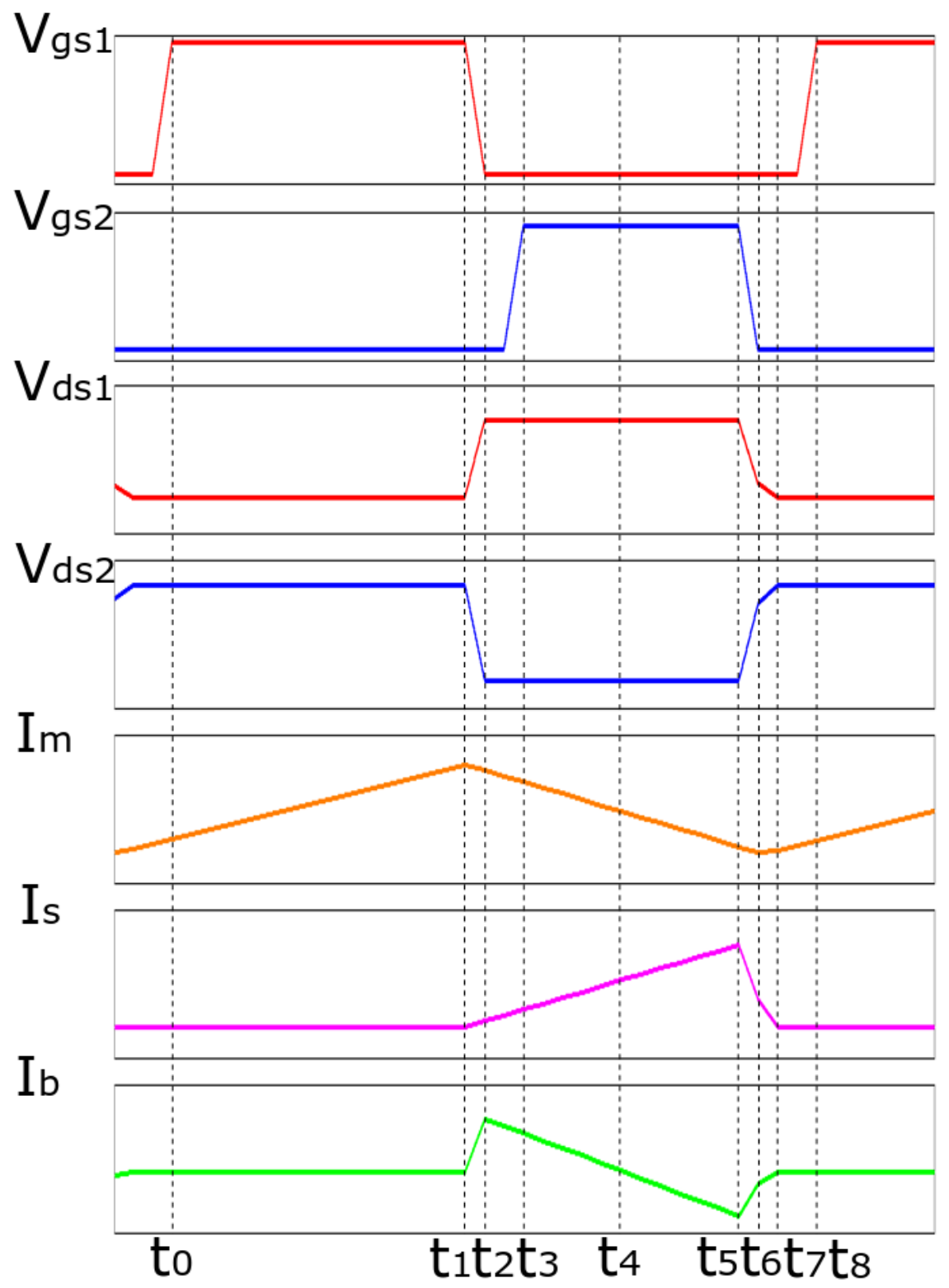

Fig. 3: Key waveform of proposed converter

\section{Turns ratio design}

For high frequency converters, planar transformers are suitable due to their excellent thermal characteristics. With ZVS, transformer losses are the main limitation for achieving high efficiency. Transformer losses consist of winding loss and core loss. The winding loss depends on the primary and secondary turns. Fig. 4 presents different turns ratios in the desired duty cycle range. In this case, turns ratio $\mathrm{n}$ is from 2.5 to 5. Considering the dead time and the boost switch turn-on time. the main duty cycle is choosing the 0.7 , and turns ratio is $1: 4$ to meet the specifications.

\section{Winding consideration}

Considering the high DC current offset of the boostflyback, winding reduce the DC resistance. Litz line and copper foil is better than PCB. Because of the core loss, secondary turns is chosen 12 . For reducing the proximity

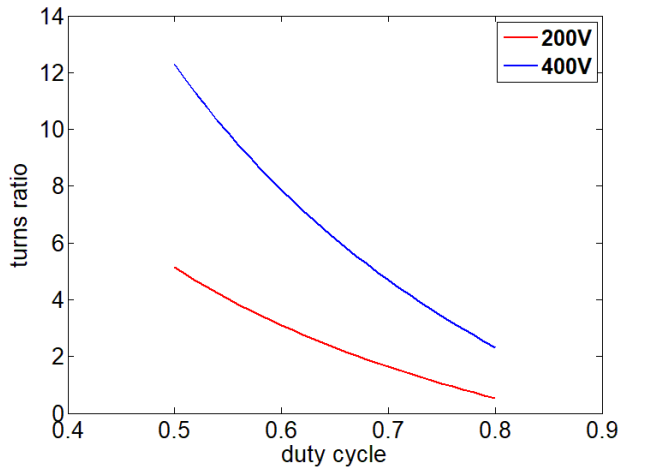

Fig. 4: turns ratio design

effect with low layer, the litz line is instead of copper foil. Primary winding used 4 litz line with $0.1 \times 60$ in parallel. 
Secondary winding used 2 litz line with $0.1 \times 20$ in parallel.

\section{COMPARED WITH FLYBACK}

\section{A. voltage stress}

High voltage stress of components is a main limitation of active flyback. For boost-flyback, the main switch voltage stress is flowing the equation (9)

$$
V_{S_{1}}=\frac{V_{i n}}{1-D}=V_{i n}+\frac{V_{f}}{n}
$$

For same output voltage, the output voltage of boost-flyback circuit flyback part is lower than the output voltage of active flyback. As the same principle, the voltage of diode D and main switch $S_{1}$ in the boost-flyback is lower than active flyback. Table I is shown the equation of all components in the boost-flyback. Where $V_{o}=V_{f}+V_{b}$. Thus, the voltage stress of boost-flyback is lower than active flyback.

\begin{tabular}{|c|c|c|}
\hline \multirow{2}{*}{ component } & \multicolumn{2}{|c|}{ voltage stress } \\
\cline { 2 - 3 } & boost-flyback & active flyback \\
\hline$S_{1}$ & $V_{i n}+\frac{V_{f}}{n}$ & $V_{i n}+\frac{V_{o}}{n}$ \\
\hline$S_{2}$ & $\frac{V_{i n}}{1-D}$ & $\frac{V_{i n}}{1-D}$ \\
\hline$D$ & $n V_{i n}+V_{f}$ & $n V_{i n}+V_{o}$ \\
\hline
\end{tabular}

TABLE I: Voltage stress of components

\section{B. power loss}

Power loss on the propose circuit consists of power loss on components and transformer.For MOSFET $S_{1}$ and $S_{2}$, power loss is composed of switching loss and conduction loss.

1) switching loss of MOSFET

Due to active flyback and the boost-flyback are achieving the ZVS, switching loss only consists of the turn-off loss. The turn-off loss is following the equation 10 :

$$
P_{o f f}=\frac{1}{2} I_{\text {peak }} V_{d s} t_{o f f} f_{s}
$$

Where $P_{o f f}$ is turn off loss of switch, $I_{\text {peak }}$ is the peak current through the switch when the switch turn off, $V_{d s}$ is the drainsource voltage of the switch, $t_{o f f}$ is the turn off transition time, and $f_{s}$ is the frequency. For the reason that the voltage stress of $S_{1}$ in the boost-flyback is lower than in the active flyback, the turn-off loss of $S_{1}$ in the boost-flyback is lower than in the active flyback, too.

\section{2) conduction loss of MOSFET}

The conduction loss of switch is calculated by the equation 11:

$$
P_{\text {con }}=I_{r m s}^{2} \times R_{d s(o n)}
$$

Where $P_{c o n}$ is the conduction power loss, $I_{r m s}$ is the RMS current of the transistor and $R_{d s(o n)}$ is the conduction resistance of the MOSFET. Because the voltage stress of the boost-flyback is lower than active flyback of main switch, we can choose the lower conduction resistance MOSFET in the propose circuit.

\section{3) diode loss}

The diode loss can be calculated by the equation (12)

$$
P_{D}=I_{F} \times V_{F}
$$

Where $P_{D}$ is the diode loss, $I_{F}$ is the RMS current through the diode while $V_{F}$ is the forward voltage of the diode. According to the loss calculation and voltage stress, Table II is shown all the component of the circuit.

\begin{tabular}{|c|c|}
\hline component & Model specification \\
\hline switch & BSC160N10N \\
\hline diode & C3D1P7060Q \\
\hline
\end{tabular}

TABLE II: component

\section{4) winding loss}

As above mentioned, winding loss is calculated by two parts. the DC loss and the AC loss. DC winding loss is calculated by the equation (13)

$$
P_{\text {wind }_{D C}}=I \times R_{D C} ; R_{D C}=\rho \frac{l}{S}
$$

Where $P_{\text {wind }_{D C}}$ is the DC part of the winding loss, I is the offset current of the winding, $R_{D C}$ is the DC resistance of winding. $\rho$ is the resistivity of copper, used as $1.7 \times 10^{-8}, 1$ is the length of the winding, $\mathrm{S}$ is the cross-sectional area of the winding. AC winding loss is flowing the equation (14)

$$
P_{\text {wind }_{A C}}=I_{a c} \times R_{A C}
$$

Where $P_{\text {wind }}$ iC is the AC part of the winding loss, $I_{a c}$ is the AC current of the winding, $R_{A C}$ is calculated in ANSYS simulation or measured on impedance analyzer.

5) core loss

Considering the core loss is calculated by $P_{\text {core }}=$ $P_{v} V_{e}$. Where $V_{e}$ is the volume of the core $P_{v}$ is calculated by equation:

$$
P_{v}=K f^{\alpha} \Delta B^{\beta}
$$

These three parameter $\mathrm{K}, \alpha$ and $\beta$ are given in datasheet of magnetic material. According the thermal situation of core, $\Delta B$ is chosen $50 \mathrm{mT}$ with ML91S. According to Faradary's law.

$$
N_{s}=\frac{V_{f}(1-D) T}{\Delta B A_{e}}
$$

Where $N_{s}$ is secondary turns. $V_{f}$ is secondary turns. $V_{f}$ is the output voltage of flyback part. $A_{e}$ is the across-sectional area of core.

\section{EXPERIMENT RESULTS}

To evaluate high step-up operation of the proposed DCDC converter can work with ZVS which validate to improve efficiency in the high frequency situation, a $100 \mathrm{~W} 1 \mathrm{MHz}$ prototype of the DC-DC converter is developed and tested in the laboratory.

Table III shows the component parameters of proposed circuit. The $1 \mathrm{MHz} 100 \mathrm{~W} 28 \mathrm{~V} / 200 \mathrm{~V}-400 \mathrm{~V}$ boost-flyback converter prototype with the proposed topology is shown in Fig.5. The control signal is generated by DG4062 function generation from RIGOL. The experimental waveform under 


\begin{tabular}{|c|c|}
\hline Component & Parameters \\
\hline rated output power $\left(P_{o} u t\right)$ & $100 \mathrm{~W}$ \\
\hline input voltage $\left(V_{i n}\right)$ & $28 \mathrm{~V}$ \\
\hline output voltage $\left(V_{o} u t\right)$ & $200 \mathrm{~V}-400 \mathrm{~V}$ \\
\hline turns ratio & $3: 12$ \\
\hline switching frequency & $1 \mathrm{MHz}$ \\
\hline magnetizing inductance & $950 \mathrm{nH}$ \\
\hline leakage inductance & $91 \mathrm{nH}$ \\
\hline output capacitor boost part & $11 \mathrm{uF}$ \\
\hline output capacitor flyback part & $6.6 \mathrm{uF}$ \\
\hline
\end{tabular}

TABLE III: Proposed Boost-flyback converter parameters

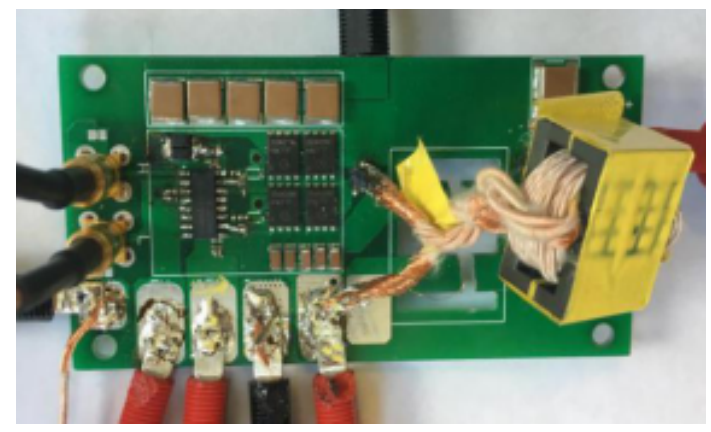

Fig. 5: Proposed Converter

full-load in output voltage $200 \mathrm{~V}$ condition and output voltage 400V condition are presented in Fig.6(a) and Fig.6(b).

Here, it shows that ZVS for both the main switch with output voltage from $200 \mathrm{~V}$ to $400 \mathrm{~V}$ can be achieved. There is a time delay between the boost switch turn-off and main switch turn-on to ensure main switch turn-on at ZVS. According to the peak current through the boost switch when turn on the boost switch is large, there is also a short time delay between the main switch turn-off and boost switch turn-on to ensure boost switch turn-on at ZVS. Fig.7 is shown the circuit efficiency with different output voltage from $200 \mathrm{~V}$ to $400 \mathrm{~V}$. The measured efficiency of the prototype is $95.3 \%$ at output voltage $200 \mathrm{~V}$.

\section{CONClusion}

In this paper, the operating principles, theoretical analysis, design methodology of a high efficiency step-up converter and experiment are presented. The boost-flyback achieve ZVS in wide output voltage range help to reduce the switch loss of main switch. The main switch voltage stress is reduced by make the flyback output capacitor and boost output capacitor in series. The experimental results have verified the predictions of the theoretical analysis. The features of this converter include high efficiency, high voltage gain and low voltage stress on the switching element.

\section{ACKNOWLEDGMENT}

The authors would like to thank to YiDou and Dehua Zhao's help in the experiment station. Thank Ouyang for patient guidance.

\section{REFERENCES}

[1] K. C. Tseng, J. T. Lin and C. C. Huang "High Step-Up Converter with Three-Winding Coupled Inductor for Fuel Cell Energy Source Applications"" in IEEE Transactions on Power Electronics, vol. 30, no. 2, pp. 574-581, Feb. 2015

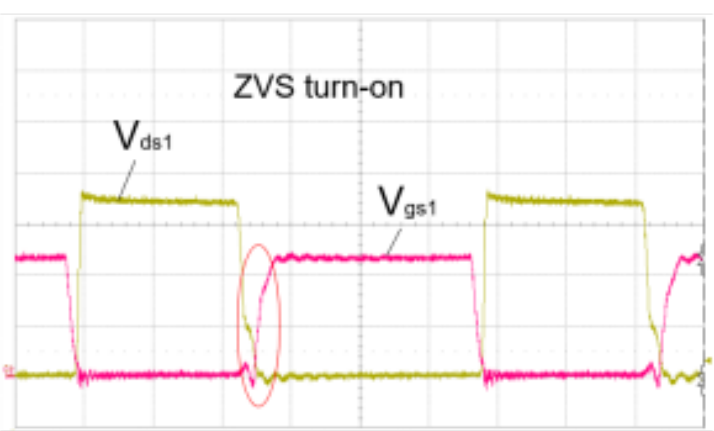

a. 200V output voltage

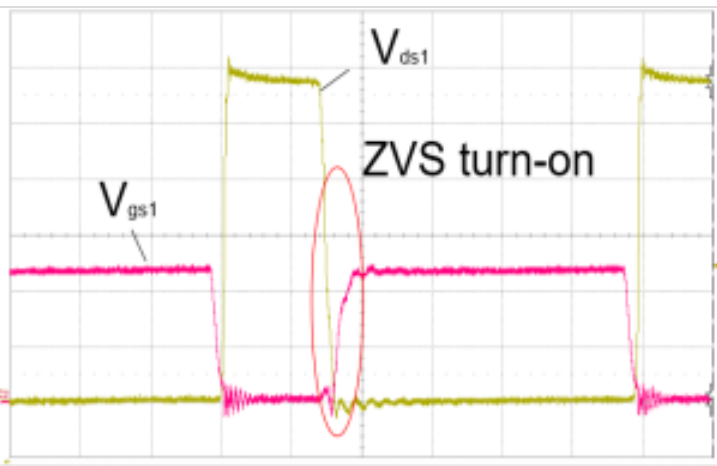

b. $400 \mathrm{~V}$ output voltage

Fig. 6: Experiment waveform for $S_{1}$ $\left(V_{d s 1}: 20 \mathrm{~V} / \mathrm{div} V_{g s 1}: 5 \mathrm{~V} / \mathrm{div}\right.$ Times:200ns/div)

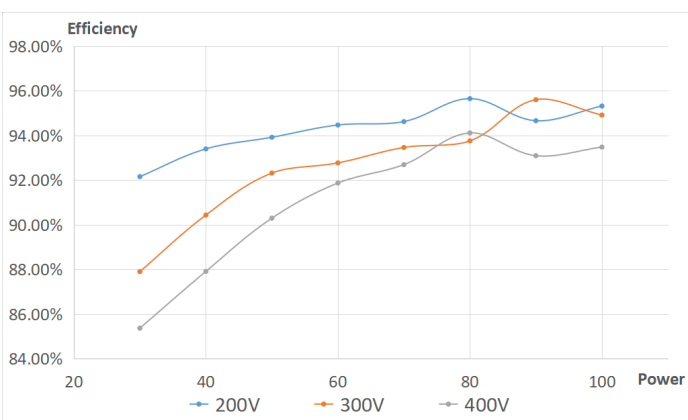

Fig. 7: Efficiency of whole output voltage range

[2] S. Sathyan, H. M. Suryawanshi, M. S. Ballal and A. B. Shitole, "SoftSwitching DC-DC Converter for Distributed Energy Sources with High Step-Up Voltage Capability," in IEEE Transactions on Industrial Electronics, vol. 62, no. 11, pp. 7039-7050, Nov. 2015.

[3] M. Forouzesh, Y. Shen, K. Yari, Y. P. Siwakoti and F. Blaabjerg, "HighEfficiency High Step-Up DC-DC Converter with Dual Coupled Inductors for Grid-Connected Photovoltaic Systems," in IEEE Transactions on Power Electronics, vol. 33, no. 7, pp. 5967-5982, July 2018.

[4] Y. P. Siwakoti and F. Blaabjerg, "Single Switch Nonisolated Ultra-StepUp DC-DC Converter with an Integrated Coupled Inductor for High Boost Applications," in IEEE Transactions on Power Electronics, vol. 32, no. 11, pp. 8544-8558, Nov. 2017.

[5] B. Zhao, Z. Ouyang, M. A. E. Anderson, M. Duffy and W. G. Hurley, "An improved partially interleaved transformer structure for highvoltage high-frequency multiple-output applications," IECON 2017 43rd Annual Conference of the IEEE Industrial Electronics Society, Beijing, 2017, pp. 798-804.

[6] S. Cui, N. Soltau and R. W. De Doncker, "A High Step-Up Ratio 
Soft-Switching DC-DC Converter for Interconnection of MVDC and HVDC Grids," in IEEE Transactions on Power Electronics, vol. 33, no. 4, pp. 2986-3001, April 2018.

[7] S. K. Changchien, T. J. Liang, J. F. Chen and L. S. Yang, "Novel High Step-Up DC-DC Converter for Fuel Cell Energy Conversion System," in IEEE Transactions on Industrial Electronics, vol. 57, no. 6, pp. 20072017, June 2010

[8] G. Wu, X. Ruan and Z. Ye, "High Step-Up DC-DC Converter Based on Switched Capacitor and Coupled Inductor," in IEEE Transactions on Industrial Electronics, vol. 65, no. 7, pp. 5572-5579, July 2018.

[9] A. Ajami, H. Ardi and A. Farakhor, "A Novel High Step-up DC DC Converter Based on Integrating Coupled Inductor and SwitchedCapacitor Techniques for Renewable Energy Applications," in IEEE Transactions on Power Electronics, vol. 30, no. 8, pp. 4255-4263, Aug. 2015.

[10] G. Wu, X. Ruan and Z. Ye, "Nonisolated High Step-Up DC-DC Converters Adopting Switched-Capacitor Cell," in IEEE Transactions on Industrial Electronics, vol. 62, no. 1, pp. 383-393, Jan. 2015.

[11] X. Ding, D. Yu, Y. Song and B. Xue, "Integrated switched coupledinductor boost-flyback converter," 2017 IEEE Energy Conversion Congress and Exposition (ECCE), Cincinnati, OH, 2017, pp. 211-216.

[12] S. W. Lee and H. L. Do, "A Single-Switch AC-DC LED Driver Based on a Boost-Flyback PFC Converter with Lossless Snubber," in IEEE Transactions on Power Electronics, vol. 32, no. 2, pp. 1375-1384, Feb. 2017.

[13] Bor-Ren Lin, Huann-Keng Chiang, Kao-Cheng Chen and David Wang, "Analysis, design and implementation of an active clamp flyback converter," 2005 International Conference on Power Electronics and Drives Systems, Malaysia, 2005, pp. 424-429 